\title{
Reflexos sonoros da querra em \\ dois romances de Erico Verissimo: \\ a música em Saga e o Prisioneiro
}

War sounds in two Erico Verissimo's novels:

the music in Saga and $O$ Prisioneiro

Gérson Luís Werlang

Universidade Federal de Santa Maria, Santa Maria, RS, Brasil

\begin{abstract}
Resumo: Dois aspectos recorrentes na obra de Erico Verissimo são a presença constante da música e suas preocupações humanistas. o humanismo levou o escritor a escrever alguns romances que tematizam conflitos bélicos importantes do século XX, notadamente, a Guerra Civil Espanhola, presente em Saga, e a Guerra do Vietnã, tematizada em 0 prisioneiro. Mesmo nesses romances, o escritor não se furta a uma de suas características, que é a presença da música. Este artigo tem por objetivo traçar a presença e escopo da música em tempos de guerra nesses dois romances.
\end{abstract}

Palavras-chave: Música e Literatura. Conflitos Bélicos. Humanismo. Erico Verissimo.

Abstract: Two recurring aspects in Erico Verissimo's works are the constant presence of music alongside his humanistic preoccupations. Humanism led him to write some novels where war is thematized, like Spanish Civil War, in Saga, and the Vietnam War, in $O$ prisioneiro. Even in these novels, music is present. This study aims to trace the presence and scope of the music in times of war in these two novels.

Keywords: Music and Literature. Armed Conflicts. Humanism. Erico Verissimo.

\section{Introdução}

A ligação de Erico Verissimo com a música está bem documentada através de múltiplos depoimentos a amigos e conhecidos ao longo de sua vida. $O$ escritor mesmo nunca escondeu seu apreço pela música e ela aparece não apenas em sua vida como é parte importante de sua obra.

1. Este ensaio é um desdobramento posterior de minha tese de doutorado, A música na obra de Erico Verissimo, publicada em 2011, e aprofunda aspectos que não foram explorados naquele momento. 
Gérson Luís

Werlang
Vários de seus livros apresentam títulos musicais: o romance Música ao longe, o conto "Sonata", o livro para crianças $O$ urso com música na barriga. A música também está presente na trama ou na estrutura de romances, contos e mesmo em livros de viagens.

Em Caminhos cruzados, Erico utiliza-se da técnica do contraponto para estruturar o romance, técnica esta proveniente do contraponto musical. Fragmentos de partituras aparecem em seus romances, e há comentários e caracterizações que envolvem os mais variados estilos, da música Barroca a Debussy, do jazz ao rock, da música folclórica a Mozart.

Outro ponto recorrente da obra do escritor é sua preocupação humanista, com a tematização de guerras, revoluções e outros conflitos bélicos que afetaram a humanidade em diferentes momentos. Em 1940, Erico Verissimo publicou seu sexto romance, Saga, depois do sucesso de público de Olhai os lírios do campo, de 1938. Saga se passa em grande parte na Espanha, uma novidade no mundo ficcional do escritor, já que seus primeiros romances se passam todos no estado natal de Erico, o Rio Grande do Sul. Há a continuidade com relação aos primeiros livros devido à presença de um personagem que aparece em várias obras anteriores, Vasco, primo de Clarissa, além da própria Clarissa. Escrito em primeira pessoa, caso único na ficção do escritor, Saga narra a busca de Vasco "rumo a um destino melhor que o justifique" (CHAVES, 2001, p. 63). Seguindo suas convicções, Vasco decide lutar na Guerra Civil Espanhola, esperando colaborar na construção de um mundo mais justo. Ao contrário do esperado, a rotina da guerra e da destruição provoca a sensação da inutilidade do conflito, e a ojeriza pela violência leva a uma posição pacifista do personagem, que retorna ao Brasil, se casa com Clarissa e vai viver no campo, local onde acredita construir um futuro tranquilo e digno para sua família. Segundo Chaves:

A participação de Vasco na guerra civil espanhola provoca uma extensão do problema da liberdade no nível do debate ideológico. Até aqui restrito ao cenário de Jacarecanga ou Porto Alegre, o romance foi acrescido duma dimensão "internacional", propondo inclusive a análise do confronto fascismo/comunismo. Isto não significa, é claro, uma tomada de posição partidária da qual o autor continua se isentando, mas comprova a coerência ideológica dentro da qual ele mantém a investigação (CHAVES, 2001, p. 65). 
Saga é um romance cuja ação se passa, portanto, durante o decurso de uma guerra, e seus personagens transitam naquele meio. Quase trinta anos depois, o escritor volta a ter a guerra como mote central de um romance seu. 0 prisioneiro é a reação de Erico à Guerra do Vietnã, e o estar em meio a um conflito armado novamente surge como motivação da trama.

Em ambos os romances, a música está presente, não negando o impulso quase natural do escritor em utilizá-la em sua obra. Este artigo se propõe a fazer uma análise da música em meio à guerra e como ela aparece nesses dois romances, separados pelo tempo, mas unos em sua relação musical-literária.

\section{Música e guerra em Saga}

No que concerne ao uso da música, Saga apresenta uma das mais interessantes construções relacionadas a elementos musicais de toda a obra de Erico Verissimo. Estruturado em quatro partes, o romance segue uma linha de raciocínio que parte do elemento épico da luta ao descanso final do guerreiro (quando Vasco retorna ao Rio Grande do Sul e se casa com Clarissa). Essa linha de desenvolvimento apresenta ligações explícitas com obras musicais, sugerindo uma leitura intertextual entre música e literatura, como um programa em uma obra musical.

A música programática ou de programa foi uma das formas criadas durante o Romantismo no qual a música apresenta um caráter narrativo ou descritivo (GROVE, 1994, p. 639). Embora existam exemplos anteriores ao Romantismo, foi naquele momento histórico que a música programática se tornou corrente na produção da maior parte dos compositores.

Nas primeiras edições de Saga, cada uma das partes que compunham o livro era precedida de uma citação musical, um fragmento de partitura cujo significado está intimamente associado ao texto que lhe segue. As citações aparecem somente nas primeiras edições do livro (pelo menos até a quinta edição) tendo sido suprimidas nas edições posteriores, caindo no esquecimento. Essas citações, no entanto, estabelecem o diálogo intertextual musical-literário e nos dão pistas preciosas sobre a estruturação da obra e sua íntima ligação com a música. 


\subsection{0 círculo de giz}

Antecedendo a primeira parte da obra, intitulada 0 círculo de giz, aparece o seguinte fragmento musical:

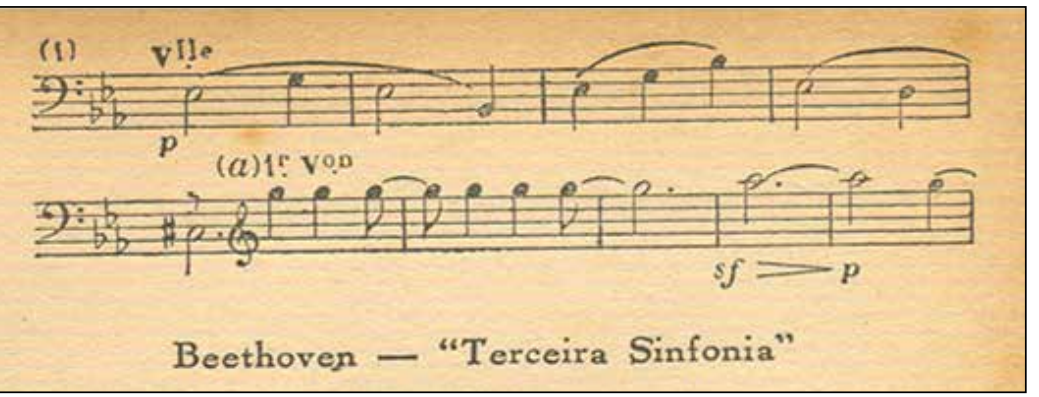

Figura 1 - Fragmento da Sinfonia nº 3, Eroica, de Ludwig van Beethoven (VERISSIMO, 1940, p. 9).

Esse fragmento, conforme aparece indicado, é parte da Terceira Sinfonia de Beethoven, conhecida como Eroica. O fragmento faz parte do primeiro movimento da obra. Composta em 1800, essa sinfonia foi originalmente concebida como uma homenagem a Napoleão Bonaparte, cuja figura e feitos Beethoven admirava. Com as posteriores guerras de conquista e tendo se sagrado imperador, o ditador decepcionou Beethoven, que riscou o nome de Napoleão da partitura e substituiu o antigo nome por Sinfonia Eroica. Beethoven procurou negar a inspiração original, dizendo que o novo nome era apropriado, já que a sinfonia exaltava feitos de coragem heroica.

Estruturada em quatro movimentos, essa obra marca a passagem do compositor para um estilo mais maduro de composição, se desvencilhando do estilo clássico utilizado no início de sua carreira na direção de um nascente romantismo musical. Segundo Nicholas Marston:

\footnotetext{
Foi com a Eroica, contudo, que Beethoven mudou de vez a natureza da sinfonia. Um dos primeiros e mais característicos produtos do que se tem denominado "fase heróica" de Beethoven - uma fase notável pela composição de obras radicais em larga escala, com freqüência estreitamente $l i-$ gadas a idéias extra-musicais -, a Eroica era muito mais longa e mais complexa do que qualquer sinfonia composta antes (MARSTON, 1996, p. 234, grifo nosso).
} 
Esse impulso rumo ao romantismo musical estabelecido por Beethoven a partir da Terceira Sinfonia (note-se que o Romantismo, em música, tem um início tardio - século XIX - se comparado com o Romantismo literário) tem relações estreitas com o impulso de Vasco de ir lutar na Espanha, um impulso heroico, similar à motivação da sinfonia:

A vida é um grande jogo e o destino, um parceiro temível que só aceita grandes paradas. Está bem. Ponho na mesa todos os meus sonhos. Não basta? Jogo então a vida. Do outro lado das montanhas fica a Espanha e a guerra. Caminho ao encontro de novas sensações. Ou da morte. Que importa? A morte também é uma aventura, a definitiva, a irremediável (VERISSIMO, 1953, p. 11).
Reflexos sonoros daguerra em dois romances de Erico Verissimo: a música em Saga e o Prisioneiro

O impulso na direção de um evento relacionado à violência e a possibilidade da morte apenas acentuam o caráter heroico presentes no início da narrativa. Esse caráter ganha corpo à medida que os voluntários, companheiros de Vasco na luta, se incorporam na guarnição que os levará para a frente de batalha.

Apesar de o caráter heroico estar bem acentuado na primeira parte da narrativa, em nenhum momento está carregado de otimismo, mas sim de uma posição crítica em relação à guerra. Vasco carrega consigo a desilusão que o faz evitar tanto o sentimentalismo carregado de alguns companheiros, como a ânsia suicida de outros. Além disso, a perda de amigos e a estupidez do conflito trazem à tona elementos que distanciam a narrativa da possibilidade de exaltação da guerra e dos feitos heroicos per se. Esse caráter reflexivo está espelhado na Eroica, onde, depois de um início otimista no primeiro movimento (Allegro con brio), apresenta-se uma reflexiva Marcha fúnebre como segundo movimento (Marcha Fúnebre: Adagio assai). Aqui, o texto musical e o texto literário se tocam, num diálogo que cabe ao leitor refazer.

Outro aspecto que estabelece um diálogo intertextual musical-literário é o tema do destino, desde o princípio citado por Vasco como uma das forças que o levaram à Espanha para lutar. Esse aspecto estabelece um diálogo direto com a Quinta Sinfonia de Beethoven, obra que é citada no texto. O personagem que catalisa esse aspecto é Marcus Silberstein, que "tem uma testa que avança alcantilada para a coroa da cabeça com o harmonioso ímpeto de uma fuga de Bach" 
(VERISSIMO, 1953, p. 134). Marcus, que chega com outros judeus austríacos, seus companheiros, para juntarem-se ao batalhão, é músico e descobre em Vasco um interlocutor:

No dia em que ele descobre o meu interesse pela música, não me abandona mais. Conta-me dos concertos que ouvia ou em que tomava parte em Viena (...) Adoro Beethoven, "aquele ser feio e quase disforme que inundou o mundo de beleza e de harmonias eternas" (VERISSIMO, 1953, p. 135).

Gérson Luís Werlang

O intertexto estabelecido mantém um permanente diálogo beethoveniano. Para Marcus, Beethoven tem um significado transcendental, que se confunde com sua própria vida:

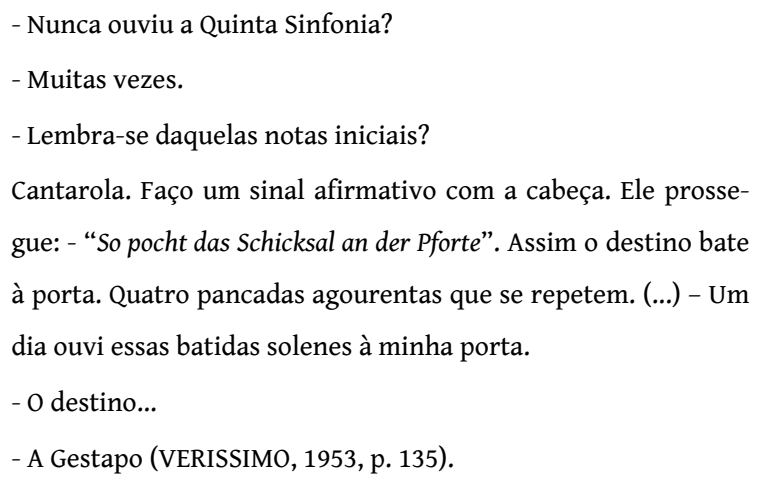

O motivo beethoveniano ecoa pela narrativa, levando a uma leitura ambígua em que a música está sempre presente, como um rio que corre paralelo a outro, o rio da literatura mesma. Essas vias paralelas que se entrecruzam a todo instante, mais como duas espirais em contínuo diálogo, abrem o caminho para a possibilidade de leitura auditiva da obra. É preciso, além de querer ouvir, abrir-se a possibilidades de escuta. Segundo Roland Barthes:

(...) ao passo que, durante séculos, a escuta foi definida como um ato intencional de audição (escutar é querer ouvir, um ato inteiramente consciente), atualmente nela reconhecemos o poder (e quase a função) de varrer espaços desconhecidos: a escuta inclui em seu campo, não apenas o inconsciente, no sentido tópico do termo, mas também, se assim podemos dizer, suas formas leigas: o que é implícito, indireto, suplementar, retardado: há uma 
Esta polissemia está presente no intertexto de Saga, no seu diálogo beethoveniano. A abertura à possibilidade de escuta do romance traz à tona ligações não entrevistas numa leitura imediata. 0 tema do destino, como uma interrogação constante, permeia toda a narrativa. À medida que essa prossegue e a luta de Saga se desenrola, os destinos dos personagens se definem, e Vasco descortina aos poucos a visão do próprio destino, diverso daquele que havia imaginado a princípio. Os caminhos de Vasco são os mesmos caminhos da Eroica de Beethoven.

\subsection{Sórdido interlúdio}

Reflexos sonoros daguerra em dois romances de Erico Verissimo: a música em Saga e o Prisioneiro

A segunda parte do romance, intitulada "Sórdido interlúdio", reafirma alguns aspectos anteriores. Encimando o título do capítulo aparece a seguinte citação da Terceira Sinfonia de Beethoven:

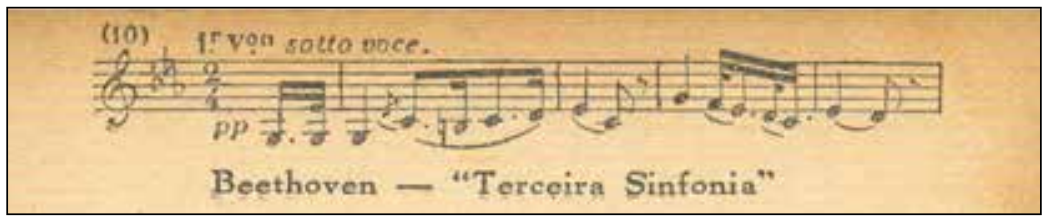

Figura 2 - Fragmento da Sinfonia nº 3, Eroica, de Ludwig van Beethoven (VERISSIMO, 1940, p. 157 ).

Esse fragmento corresponde ao início do segundo movimento da Eroica, justamente a Marcha Fúnebre citada anteriormente. A ligação dessa seção do romance com a Marcha se torna evidente pela tomada de consciência de Vasco da condição absurda da guerra. Essa seção é a mais breve das quatro partes do romance, caracterizando o título "Interlúdio", palavra que também apresenta ligações musicais. Um interlúdio é "um trecho tocado ou cantado entre as partes principais de uma obra maior, como uma ópera" (GROVE, 1994, p. 459). A brevidade do capítulo o caracteriza como um interlúdio, mas também reforça a intenção musical do romance: o capítulo se constitui numa parte breve entre duas seções musicais (capítulos) maiores.

A relação já antevista, por estar implícita na citação da Terceira Sinfonia, no sentido de uma reflexão sobre o heroísmo, a morte e o significado da guerra, alcança o ponto culminante na Marcha Fúnebre, para onde confluem tanto a Eroica como Saga, no sentido da tomada de 
consciência e também de uma posição ideológica, uma opção pela nãoviolência, ou ao menos pela visão da inutilidade da guerra como recurso para solucionar diferenças.

Com o fim iminente do conflito, fugitivos e soldados são levados a um campo de refugiados, onde as condições são precárias e a morte ronda o tempo todo. $O$ intertexto com a Marcha Fúnebre é claro:

Passam-se os dias. A miséria da condição humana me parece infinita. Manifesta-se de mil modos grotescos e trágicos (...)

Gérson Luís Werlang
Vamos sendo comidos e sugados aos poucos. Por dentro pelos bacilos da colite e por fora, pelos parasitas (...) A disenteria faz dezenas de vítimas. Não temos recursos para os medicar. Há homens que caem e se entregam (VERISSIMO, 1953, p. 199-200).

Assim como o "ponto nevrálgico" (FIELD, 1995) da Eroica é o segundo movimento, também o é a segunda parte de Saga. "Sórdido Interlúdio" pode ser considerado o momento reflexivo da obra, que estabelece múltiplas ligações com elementos musicais. Há a ligação com a Marcha Fúnebre, mas também há a alusão à chamada do destino que determina o que Vasco chama de "o pobre peru ébrio que retorna ao seu círculo" (VERISSIMO, 1953, p. 213).

\subsection{0 destino bate à porta}

A terceira parte da obra mantém as ressonâncias beethovenianas ao prenunciar, já no título, as ligações com a Quinta Sinfonia. Encimando o título aparece a seguinte citação:

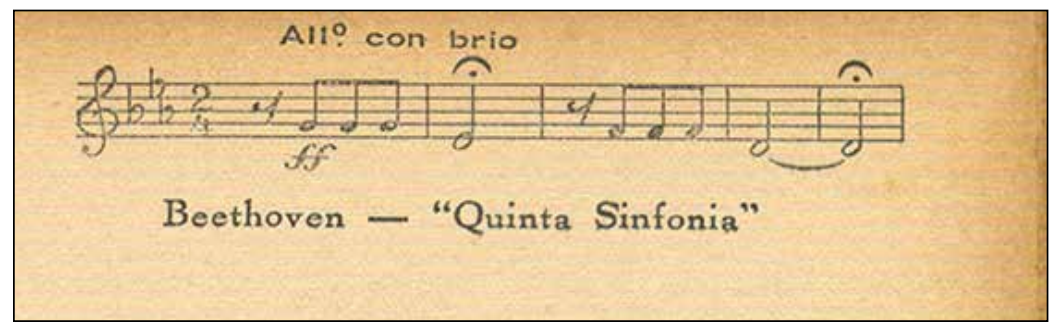

Figura 3 - Fragmento da Sinfonia nº 5, de Ludwig van Beethoven (VERISSIMO, 1940, p. 169).

O fragmento citado corresponde ao início do primeiro movimento da Quinta Sinfonia de Beethoven, o conhecido "tema do destino". Tantas vezes prenunciado dentro de Saga, o motivo do destino define a for- 
ma do livro. De todos os romances de Erico Verissimo, Saga é o que mais se aproxima de uma forma sinfônica. Possui quatro movimentos bem estruturados (quatro partes), o segundo movimento é lento (a ligação com a Marcha Fúnebre dá o tom grave, de andamento lento da segunda parte), como costumam ser os segundos movimentos das sinfonias, e o último movimento é um allegro (a última seção onde Vasco encontra a solução para o seu destino). Não é de estranhar a chamada solução "romântica" do romance, já que ele se inscreve claramente num plano dominado por uma estrutura romântica. As sinfonias que compõem o intertexto de Saga são obras fundamentais e constituem passos decisivos rumo ao nascente romantismo musical do século XIX. Como o intertexto

sinfônico é indissociável, é natural que a estrutura do romance contenha elementos marcantes do Romantismo, principalmente na sua parte final.

Reflexos sonoros daguerra em dois romances de Erico Verissimo: a música em Saga e o Prisioneiro niano, ao se apropriar do tema do destino da Quinta Sinfonia, tantas vezes prenunciado no romance. A Quinta Sinfonia, composta simultaneamente à Sexta Sinfonia nos anos de 1807-08, foi estruturada em quatro movimentos, na tonalidade principal de dó menor, sendo eles: I - Allegro con brio; II - Andante con moto; III - Allegro; IV - Allegro. O tema do primeiro movimento citado no início da terceira parte está estreitamente relacionado com o impulso de Vasco na descoberta do seu destino: a princípio voltar para casa, fazer da luta cotidiana dentro de sua província a sua luta, em vez de recorrer a uma luta de pessoas estranhas num país distante. Tendo-se em mente a estrutura sinfônica do romance, o impulso heroico do início (primeiro movimento) se desfaz na visão da inutilidade e sordidez da guerra no segundo movimento (segunda parte), que leva à busca de Vasco pelo seu destino (terceiro movimento). Essa busca se revela diferente do que Vasco a princípio imaginara, a luta cotidiana na cidade traz conflitos, o início da Segunda Guerra evoca a sensação de aniquilação, de fim da civilização.

\subsection{Outros aspectos musicais}

Sob o aspecto da paisagem sonora, Saga obtém, em relação aos outros livros de Erico, "o acréscimo de uma dimensão internacional" (CHAVES, 2001, p. 63). Se os romances anteriores do autor têm como cenário Porto Alegre ou Jacarecanga, Saga apresenta uma paisagem sonora inédita, uma paisagem que em verdade Erico não conhecia pessoalmente, e que deve ter-lhe valido esforços de pesquisa e imaginação para poder reconstituir-recriar. Esse aspecto é importante na medida em que o es- 
Gérson Luís

Werlang critor experimenta pela primeira vez uma paisagem que não é a sua imediata, e que trará reflexos futuros em obras variadas, principalmente em 0 prisioneiro e 0 senhor embaixador.

Os primeiros elementos musicais do romance ocorrem quando Vasco se surpreende justamente com esse aspecto fundamental do estrangeiro, do que não é do lugar: a estranheza. "Alguém canta uma canção saltitante numa língua que não consigo identificar" (VERISSIMO, 1953, p. 19), observa Vasco ao chegar ao local onde são arregimentados os voluntários. Nesse momento, nenhum aspecto lhe passa despercebido, as vozes, as cores, a variedade dos sons daquela região desconhecida para ele. "Quando lhe pergunto por que vai lutar na Espanha, responde com sua voz oleosa, de modulações musicais" (VERISSIMO, 1953, p. 19), diz a respeito de um de seus companheiros. Ao passar por um guarda, ainda na divisa da França com a Espanha, nota que ele "o contempla com ar divertido e ao cabo de alguns segundos cantarola, sorridente: - Tout va trés bien, madame la marquise... Allez!" (VERISSIMO, 1953, p. 21). A cor local espanhola é acrescida da dimensão multi-étnica e cultural dos voluntários que se unem à luta contra Franco. "Dois italianos cantam uma canção guerreira que mais tarde venho a saber que se chama 'Bandiera Rossa'(VERISSIMO, 1953, p. 22)”, observa. A própria mistura de línguas produz uma sonoridade diferente, que não lhe escapa: "Palavras de várias línguas se cruzam e se misturam no ar. Um espetáculo para os olhos, uma festa para os ouvidos" (VERISSIMO, 1953, p. 23). Esta "festa para os ouvidos" é quase uma constante no romance, mas que se perde nos momentos de batalha, onde sobra espaço apenas para o medo e o desespero.

"O velho sino da estação foi pelos ares badalando 'como um passarito ferido"' (VERISSIMO, 1953, p. 25), diz o estacionário de Portbou para Vasco; "eu lhe digo que esse sino era como uma pessoa da minha família. Tinha um som tão bonito..." (VERISSIMO, 1953, p. 25), revela ele mais adiante. A paisagem sonora também é arruinada pela guerra. A guerra destrói os símbolos quotidianos que provêem segurança, conforto. $O$ processo da barbárie é o da aniquilação dos elementos humanizantes, entre eles a música. "Quando eu batia os sinais, dlem, dlem, ele parecia dizer 'papai, papai...'Franco me pagará” (VERISSIMO, 1953, p. 25), conclui o estacionário. Mas a marcha para a guerra é uma marcha colorida, onde os "voluntários comem, falam, fumam e cantam" (VERISSIMO, 1953, p. 27). Em meio à marcha, elementos da paisagem sonora da vida quotidiana das pessoas ainda são encontrados pelo caminho, e se tornam motivo 
de regozijo entre os voluntários. A ida a um prostíbulo da região provoca mais prazer pelo que há de normalidade em meio à guerra que pelas mulheres. A música é um elemento catalisador dos ânimos: "Vemos alguns homens entrar numa casa de onde saem os sons roucos dum gramofone (...) - Música! - murmura Brown (...) No meio da balbúrdia rouqueja um ragtime" (VERISSIMO, 1953, p. 29).

$\mathrm{Na}$ marcha para o sul rumo à guerra, a paisagem sonora é também a paisagem individual de cada voluntário, que contribui com a cor local de seu país. Sebastian Brown, negro norte-americano, traz consigo as marcas musicais de seu país. "Sebastian Brown começa a cantarolar um desses "spirituals" dos negros americanos. A melodia tem uma funda ternura humana e é ao mesmo tempo duma límpida simplicidade infantil" (VERISSIMO, 1953, p. 36). Note-se que agora os voluntários seguem rumo ao sul da Espanha tendo como meio de transporte o trem, e é nesse contexto que Sebastian inicia seu canto. 0 trem é profundamente arraigado à tradição da música negra norte-americana, notadamente o blues. Segundo Muggiatti:

\footnotetext{
Trens e trilhos correm como sangue pelas veias do blues. A ferrovia não é um mero meio de transporte, é quase um veículo mágico que leva o negro a transcender a sua condição. Viagem, união, separação: o trem adquire no blues uma dimensão mitológica. Não à toa, o sistema de fuga usado pelos abolicionistas antes da Guerra Civil para ajudar escravos a ganharem a liberdade nos Estados do Norte foi chamado de Underground Railroad, Ferrovia Subterrânea. Era uma rede de casas amigas ("estações") nas quais os negros se abrigavam à noite durante sua escapada (MUGGIATTI, 1995, p. 29).
}

Não é casual, portanto, o fato de Sebastian Brown cantar justamente quando o meio de transporte utilizado é o trem. Sebastian canta um spiritual, estilo de lamento relacionado ao blues, mas de conotação religiosa, "um tipo de canção folclórica que teve origem com a prática evangelizadora nos EUA, entre 1740 e final do séc. XIX" (GROVE, 1994, p. 893). Vários voluntários que viajam naquele vagão se sentem comovidos ou afetados pela melodia:

Axel sorri apertando a haste do cachimbo com dentes muito claros. Garcia escuta em silêncio. E como eu me mostro também interessado, Sebastian começa a cantar mais alto. Em bre-
Reflexos sonoros daguerra em dois romances de Erico Verissimo: a música em Saga e o Prisioneiro 
ve sua voz de veludo enche o vagão, é como um gemido que sai de funda caverna escura cheia de ressonâncias misteriosas (VERISSIMO, 1953, p. 36).

A marcha em direção à guerra é, portanto, um espetáculo colorido, musical e multi-étnico. Canções de voluntários de diferentes países se misturam às cores locais para formar a paisagem sonora dos ambientes por onde passam. A luta na Brigada Internacional é, antes de tudo, um ato de heroísmo em defesa do ideal socialista, heroísmo que é cantado, comemorado, cultivado. Esse caráter de júbilo por estar indo à guerra está estrei-

Gérson Luís Werlang tamente relacionado ao plano da primeira parte da obra, 0 círculo de giz, que por sua vez mantém conexões com o primeiro movimento da Eroica: o caráter de alegria heróica, relacionada à coragem, do primeiro movimento.

Na segunda parte do romance, "Sórdido interlúdio", há poucas observações relativas à música. A situação de degradação em que se encontram as pessoas que procuram fugir do conflito é pouco propícia à presença da arte. Essa característica se repete em outros textos de Erico, notadamente em 0 prisioneiro. Em momentos nos quais predomina a barbárie não há lugar para a música. A música se transforma numa mera lembrança de tempos melhores: "É doloroso e mesmo desanimador pensar que a alguns quilômetros de onde nos encontramos existem cidades onde as criaturas vivem normalmente, bebem água pura, comem alimentos sãos, ouvem música e sabem sorrir" (VERISSIMO, 1953, p. 206, grifo nosso).

À medida que a situação se degrada, o distanciamento da arte se torna, como o distanciamento da vida, mais agudo. A Marcha Fúnebre da Terceira Sinfonia se manifesta, lenta, contundente. "A situação piora de dia para dia. Já não se ouvem cantigas. Calou-se a vitrola que rouquejava não sei onde tangos e paso-dobles" (VERISSIMO, 1953, p. 206). 0 resgate de Vasco do campo de refugiados vem mudar o destino do personagem, anunciando a próxima seção do romance.

O retorno a Porto Alegre corresponde ao retorno à paisagem $\mathrm{mu}$ sical dos livros anteriores de Erico, acrescido do aspecto beethoveniano do romance. Logo ao chegar, Vasco é interpelado pela polícia, que queria saber o que fora fazer na Espanha, se era comunista, colocando-o perante o sistema repressivo da época. Vasco teme pelo seu destino e observa que "neste momento estão a me martelar na cabeça as quatro notas iniciais da Quinta Sinfonia de Beethoven. Talvez o destino esteja agora batendo à minha porta" (VERISSIMO, 1953, p. 214). Mas o destino 
já havia batido à porta quando Vasco fora resgatado do campo de refugiados e seu futuro, embora incerto, revelava a possibilidade otimista da convivência com a família e os amigos.

Vale observar que muitas das experiências de Vasco em suas andanças pela Espanha são como notas do romancista que colhe material para o futuro. Ao falar dos homens de seu batalhão, Vasco observa que "conversam, fumam, bebem e cantam juntos como bons camaradas que se encontram agora aqui para se separarem mais adiante sem aviso prévio nem manifestações de sentimentalismo", e conclui logo adiante: "A paz para eles seria dolorosa e a vida se lhes tornaria insuportável" (VERISSIMO, 1953, p. 59). Ora, não é este o comportamento errático de muitos personagens de 0 tempo e o vento, na sua inconstância e inadaptabilidade para a vida cotidiana durante os tempos de paz, sempre

Reflexos sonoros daguerra em dois romances de Erico Verissimo: a música em Saga e o Prisioneiro prontos para entrar em guerra? Muitas conclusões de Vasco apontam o rumo que tomaria a obra de seu criador. Em outro momento, quando convalescente de um ferimento em um hospital de Barcelona, Vasco é inquirido por seus colegas de quarto do motivo de sua vinda para lutar na Espanha. "Que é que está fazendo aqui? Não tinha na sua terra um relógio para consertar... um pedaço de terra para lavrar?" Vasco parece ter sido pego de surpresa. Dom Miguel, outro colega de Vasco conclui: "É bastante estranhável que com tanta coisa a construir num país novo como o seu, você tenha vindo para cá ajudar estes pobres loucos a destruir a velha Espanha" (VERISSIMO, 1953, p. 159). Talvez Erico tenha feito a si mesmo essa mesma pergunta a respeito do rumo de sua obra.

\section{0 prisioneiro}

O prisioneiro foi o penúltimo romance escrito por Erico Verissimo. Publicado em 1967, o livro foi considerado por muitos como um corpo estranho na obra do escritor. No entanto, como aponta Antonio Hohlfeldt, "basta uma leitura atenta do texto para que fique evidente a afoiteza e o equívoco da acusação, até porque a novela é, de certa maneira, um aprofundamento das preocupações do escritor naquele momento" (HOHLFELDT, 2003, p. 94). A insistência da crítica em atribuir um sentido de estranheza às obras dessa fase apenas demonstra o despreparo em que ela se encontrava naquele momento para analisar as inovações na obra do escritor. Esperava-se dele a repetição das obras anteriores, e quando isso não se confirmava, uma posição anômala era geralmente atribuída aos novos romances. 
Escrito no momento histórico em que os Estados Unidos estavam envolvidos na Guerra do Vietnã, Erico registra no romance (ou novela, como querem alguns) suas preocupações a respeito da guerra, da violência institucionalizada ou não, do imperialismo, do racismo, da desumanização da vida no último quarto do século XX. Muitos viram na obra certo panfletarismo, mas o passar do tempo tem desmentido a afirmação. Segundo Flávio Loureiro Chaves:

Como 0 prisioneiro foi publicado no momento em que a Guerra

Gérson Luís Werlang do Vietnã alcançava seu ponto crítico, no auge do envolvimento norte-americano no conflito, muitos o receberam como panfleto ou documento, mais um entre os muitos com que Erico Verissimo sempre fez questão de marcar sua posição diante dos fatos políticos que, no Brasil ou no exterior, exigiram o seu pronunciamento de cidadão (...) Superada a conjuntura transitória em que a novela nasceu, sua releitura apresenta alguns pontos de contato com Noite (CHAVES, 2001, p.127).

O livro não apresenta numeração de capítulos. A narrativa é separada apenas por espaços em branco entre o que poderiam ser as seções da obra. Os personagens não têm nomes, que são substituídos pelas suas funções, profissões, patentes no exército ou por suas relações de parentesco. O nome de nenhum país envolvido no conflito é diretamente citado na trama, nem a nacionalidade de qualquer personagem. A não-citação de nomes de países é deliberada, num período (1967) em que o público leitor poderia identificar com facilidade a que se referia a história. Tampouco as línguas faladas pelos personagens são citadas no decorrer da narrativa, embora fique claramente dedutível a que nacionalidade se refere o narrador quando fala de cada personagem.

A narrativa fixa-se em torno de um fato que se encontra na parte final do livro, o aprisionamento de um terrorista que havia plantado uma bomba em algum lugar da cidade ocupada e que deve ser interrogado num curto período de tempo para que se evite o morticínio de pessoas inocentes. Dessa função é incumbido um tenente negro (a rigor mulato), que acaba por confrontar seus próprios traumas no decorrer do interrogatório. 0 prisioneiro acaba sendo torturado e morto.

Toda a narrativa anterior a esse episódio se constitui numa longa reflexão de diferentes personagens a respeito de suas situa- 
ções sociais e reflete questões como as prisões sociais (o casamento), o racismo, a violência, em tempos de guerra ou não. Mais que o terrorista aprisionado ou o tenente negro e seus complexos, todos os personagens da obra são prisioneiros que buscam algum tipo de libertação. O coronel branco é prisioneiro de um casamento infeliz e das convenções sociais que o prendem a essa situação e ele encara a guerra como uma espécie de trégua para os problemas de sua vida, enquanto outro personagem, o major, é prisioneiro da tirania de sua mãe. O próprio tenente parece caminhar, inexoravelmente, para a autodestruição a partir do momento em que constata a impossibilidade de resolver os traumas sociais e raciais existentes em seu país e que o acompanham mesmo numa terra distante.

Reflexos sonoros daguerra em dois romances de Erico Verissimo: a música em Saga e o Prisioneiro

\section{Música e guerra em 0 prisioneiro}

o prisioneiro apresenta características únicas na obra do escritor, onde vários estilos de música estão presentes, entremeados em diversos momentos da narrativa. Com relação ao uso da música, há uma tendência à concisão que já havia sido esboçada em Noite e $O$ senhor embaixador, e que permanece em 0 prisioneiro. Há ainda outro fato que torna o livro especial no que concerne à questão musical, que é a ausência da mesma em grande parte da narrativa. Quando a violência se torna predominante, a música desaparece. Há paralelos que podem ser traçados com obras anteriores do escritor, notavelmente, em Saga, onde nos momentos em que a guerra e as condições nos campos de refugiados se deterioram, também a música se torna escassa ou inexistente. Mas em 0 prisioneiro, durante toda a longa seção em que o terrorista é torturado, desaparecem quaisquer sinais usuais de elementos musicais na obra do escritor. Erico claramente alia a música à vida, e é uma característica sua eliminá-la nos momentos onde a desumanidade, a violência, a guerra e a destruição predominam. Afora esta característica crucial, 0 prisioneiro apresenta, em sua parte inicial, citações musicais com certa abrangência estilística, numa gama que vai da música erudita ao jazz, ao tango e até mesmo ao rock.

\subsection{Jazz}

A presença do jazz em 0 prisioneiro possui uma dimensão que também apresenta características únicas na obra do escritor. Quando o tenente rememora fatos de sua vida num quarto de hotel, lembra-se do momen- 
to em que seu pai se suicidara por não suportar as pressões de uma sociedade racista. Pouco depois do enterro, algo inesperado acontece:

Quando o cortejo se dispersara, a mãe lhe dera a mão e ambos dirigiram-se para o portão do cemitério. Ela enxugava com o lenço as lágrimas silenciosas. Ele caminhava perdido em seus pensamentos confusos. Quase pisara distraído numa rosa amarela caída no chão. Sons alegres no ar. Um outro cortejo fúnebre entrava no cemitério. Fúnebre? Um jazz-band vinha à frente, comandado por um negro

Gérson Luís Werlang reluzente vestido de branco, a requebrar-se, risonho, com um estandarte tricolor nas mãos. Pistons, trombones, clarinetas, pratos, bombo, tambores! Os instrumentos de metal chispavam ao sol, tocando uma vibrante marcha triunfal (VERISSIMO, 1997, p. 59).

Seu pai enterrado, o jazz-band parecia anunciar a possibilidade de novos tempos. A alegria dos músicos era contagiante e contrastava com o fato de ser aquele um cortejo fúnebre: o jazz-band era um arauto da esperança para o menino mulato:

(...) o cortejo fazia evoluções coreográficas por entre as sepulturas. Então ele sentiu como nunca a alegria de estar vivo. Era como se estivesse saindo de um prolongado pesadelo. Um pensamento se formou em sua mente: Agora que "ele" está morto, nós dois poderemos viver como brancos! (VERISSIMO, 1997, p. 60)

A esperança do menino de escapar de sua condição racial, no entanto, revela-se uma ilusão, pois não é possível deixar para trás o que se é. Nesse sentido, o jazz-band encerra essa contradição. $O$ jazz, música nascida em New Orleans, nos Estados Unidos, na virada do século XIX para o século $\mathrm{XX}$, tem suas raízes firmemente encravadas na cultura negra. A profunda identificação do menino com a música, como que anunciando a possibilidade de novos tempos, trazia consigo o fato de que a própria música que lhe ensejava a idéia de se livrar de sua condição era de origem miscigenada, ou seja, o fator racial estava impregnado na cultura e na sociedade. Segundo François Billard: "O jazz é de raça indeterminada. Negro, sim... Mas que grau de negritude? Esse detalhe tem sua importância. Negro de azeviche, café com leite, todas as nuances são abrangidas" (BILLARD, 2001, p. 9). 
A esperança do menino em ser branco, refletida na alegria que a música lhe provoca, é, portanto, ilusória. A música mesma encerra a profunda contradição a que está sujeito o tenente naquele momento de sofrimento.

\subsection{Vozes da contracultura}

Uma das citações musicais presentes em 0 prisioneiro envolve um estilo musical que nunca havia surgido antes na obra do escritor: o rock. A existência dessa citação nos dá mais uma demonstração da sintonia de Erico com a sua época, adiantando cenas que veríamos no cinema mais de uma década depois da publicação do romance, cenas onde o rock é a trilha sonora:

\footnotetext{
Entrou no café, onde soldados e civis bebiam, sentados às mesas ou de pé, junto ao balcão, quase todos acompanhados de mulheres nativas. Uma eletrola automática enchia o ar da estridência das guitarras elétricas e das vozes guturais dum quarteto misto que, para o tenente, parecia refletir, numa obsessão desesperada, a mesma frase de três palavras (VERISSIMO, 1997, p. 103).
}

Reflexos sonoros daguerra em dois romances de Erico Verissimo: a música em Saga eo Prisioneiro

Esta é a primeira, embora não única, presença do rock na obra do escritor. Tal detalhe poderia ser insignificante, não fosse o momento histórico em que se vivia. A Guerra do Vietnã foi o conflito que provocou uma das maiores e mais importantes reações da juventude contra uma guerra ou os desmandos de uma nação já documentadas historicamente. Não apenas os Estados Unidos, mas vários países assistiram a protestos veementes contra a guerra, o que gerou um movimento que encontra reflexos no mundo até hoje: a contracultura, um movimento considerado como uma forma alternativa de cultura que tem como objetivo combater os valores culturais vigentes, considerados decadentes.

Esse movimento está profundamente conectado a várias expressões artísticas e culturais e estabelece e estreita laços com culturas que até então (meados dos anos sessenta) não eram significativas no âmbito da sociedade ocidental. 0 contato com filosofias orientais, a liberação sexual, a conscientização ecológica foram sedimentados pelo movimento da contracultura. Um dos aspectos fundamentais do movimento era o rock, meio de expressão mais importante da juventude da época. Um grande número de bandas circulava por festivais, tocando em parques, eventos variados ao ar livre, onde os protestos contra a guerra aconteciam. Músicos importantes do pe- 
ríodo, como o guitarrista Jimi Hendrix ${ }^{2}$, faziam parte desse cenário. $\mathrm{O}$ som da guitarra de Hendrix, tocando o hino nacional norte-americano numa versão para guitarra solo, no qual transpareciam entre a melodia do hino ruídos que imitavam o som de metralhadoras, foi um dos momentos cruciais da música do período e um dos protestos artísticos mais contumazes já vistos contra a guerra. Nesse sentido, Hendrix era um símbolo da época. Como aponta Friedlander ao comentar o álbum Band of Gypsies de Hendrix:

Gérson Luís Werlang

Os concertos resultaram num álbum homônimo gravado ao vivo, que contava com uma jóia rara de 12 minutos e 38 segundos: Machine Gun. Hendrix dedicou a canção a todos os homens que lutavam no Harlem, Chicago e Vietnã. Machine Gun é o melhor exemplo disponível de um lançamento de uma grande gravadora que exibe a visão multifacetada que Jimi tinha da guitarra. Estão presentes as repetições, as notas dilacerantes do blues aliadas a um caleidoscópio cambiante de riffs guiados pela amplificação e distorção sonoras (FRIEDLANDER, 2004, p. 319).

Debates contra o racismo e a violência estavam na ordem do dia e a música era o meio mais eficaz de colocar idéias em discussão. Hendrix, um músico descendente de negros, sentiu na pele o preconceito e não se esquivou de discutir essas questões. Friedlander (2004, p. 319), ao comentar sobre "Machine Gun", diz: “A letra de Machine Gun ataca uma guerra que ele (Hendrix) descreve como sendo conduzida contra negros e vietnamitas, pelo 'homem diabólico"'. Sobre isso, Hendrix (apud FRIEDLANDER, 2004, p. 319) comenta: "Eles nos (soldados americanos) forçam a matar você e você me matar mesmo que nós sejamos somente famílias separadas pela distância".

A sintonia da obra de Erico Verissimo com esses fatos é completa e 0 prisioneiro alia a sua voz às vozes da contracultura.

\section{Considerações finais}

A relação de Erico Verissimo com a música encontra, em sua obra, ecos quase improváveis. Para além de sua utilização como elemento que compõe o cenário sonoro de um romance, como trilha sonora de uma

2. James Marshall Hendrix (1942-1970): músico norte-americano, considerado um dos mais importantes e influentes guitarristas de todos os tempos. Ultimamente, críticos de vários países têm salientado a importância de Hendrix, considerado-o um dos grandes gênios da música que o rock produziu. Para maiores referências, ver o trabalho de Chris Potash, The Jimi Hendrix Companion. 
determinada época, ou como caracterização de um ou mais personagens, o escritor é capaz de transcender os cenários mais prováveis em que a música pode ser utilizada.

Nesse contexto, a música presente em conflitos bélicos exprime uma posição de resistência perante o que há de mais destrutivo na natureza humana. A música, portanto, reflete o humanismo do escritor, além de fornecer um depoimento intertextual dentro do texto literário, enriquecendo a paleta expressiva de sua obra.

Os sons da guerra em Saga e 0 prisioneiro, duas obras separadas por um lapso de tempo de quase trinta anos, reafirmam esse compromisso artístico e social do escritor.

Reflexos sonoros daguerra em dois romances de Erico Verissimo: a música em Saga eo Prisioneiro

\section{REFERÊNCIAS BIBLIOGRÁFICAS}

BARTHES, Roland. o óbvio e o obtuso. Traduzido por Lea Novaes. Rio de Janeiro: Nova Fronteira, 1990.

BILLARD, François. No mundo do jazz. Traduzido por Eduardo Brandão. São Paulo: Companhia das Letras, 2001.

CHAVES, Flávio Loureiro. Erico Verissimo: o escritor e seu tempo. Porto Alegre: UFRGS, 2001.

FIELD, John. Ludwig van Beethoven. In: Beethoven, melodic masterpieces. Polydisc 479 200, 1995.

FRIEDLANDER, Paul. Rock and roll: uma história social. 3.ed. Traduzido por A. Costa. Rio de Janeiro: Record, 2004.

GROVE. Dicionário Grove de música. Editado por Stanley Sadie. Rio de Janeiro: Zahar, 1994.

HOHLFELDT, Antonio. Terra de contrastes. Cadernos de literatura brasileira. São Paulo: Instituto Moreira Salles, nº 16, 2003.

MARSTON, Nicholas. Sinfonias. In: COOPER, Barry (Org.). Beethoven, um compêndio. Rio de Janeiro: Zahar, 1996. 
MUGGIATTI, Roberto. Blues, da lama à fama. São Paulo: 34, 1995.

POTASH, Chris. The Jimi Hendrix Companion: three decades of commentary. New York: Omnibus Press, 1996.

VERISSIMO, Erico. O prisioneiro. 21. ed. São Paulo: Globo, 1997. Saga. 1. ed. Porto Alegre: Globo, 1940.

Gérson Luís Saga. Porto Alegre: Globo, 1953.

Werlang

WERLANG, Gérson. A música na obra de Erico Verissimo: polifonia, crítica social e humanismo. Passo Fundo: Méritos, 2011.

Recebido em 17 de agosto de 2015

Aceito em 14 de outubro de 2015 